University of Nebraska - Lincoln

DigitalCommons@University of Nebraska - Lincoln

USDA National Wildlife Research Center - Staff Publications
U.S. Department of Agriculture: Animal and Plant Health Inspection Service

$11-2015$

\title{
Improving the odds: Assessing bait availability before rodent eradications to aid in selecting bait application rates
}

\author{
Madeleine Pott \\ Island Conservation, madeleine.pott@islandconservation.org \\ Alexander S. Wegmann \\ Island Conservation \\ Richard Griffiths \\ Island Conservation \\ Araceli Samaniego-Herrera \\ University of Auckland \\ Richard J. Cuthbert \\ Royal Society for the Protection of Birds
}

See next page for additional authors

Follow this and additional works at: https://digitalcommons.unl.edu/icwdm_usdanwrc

Part of the Life Sciences Commons

Pott, Madeleine; Wegmann, Alexander S.; Griffiths, Richard; Samaniego-Herrera, Araceli; Cuthbert, Richard J.; de L. Brooke, M.; Pitt, William C.; Berentsen, Are R.; Holmes, Nick D.; Howald, Gregg R.; Ramos-Rendon, Karina; and Russell, James C., "Improving the odds: Assessing bait availability before rodent eradications to aid in selecting bait application rates" (2015). USDA National Wildlife Research Center - Staff Publications. 1665.

https://digitalcommons.unl.edu/icwdm_usdanwrc/1665

This Article is brought to you for free and open access by the U.S. Department of Agriculture: Animal and Plant Health Inspection Service at DigitalCommons@University of Nebraska - Lincoln. It has been accepted for inclusion in USDA National Wildlife Research Center - Staff Publications by an authorized administrator of DigitalCommons@University of Nebraska - Lincoln. 


\section{Authors}

Madeleine Pott, Alexander S. Wegmann, Richard Griffiths, Araceli Samaniego-Herrera, Richard J. Cuthbert, M. de L. Brooke, William C. Pitt, Are R. Berentsen, Nick D. Holmes, Gregg R. Howald, Karina Ramos-

Rendon, and James C. Russell 
Special Issue Article: Tropical rat eradication

\title{
Improving the odds: Assessing bait availability before rodent eradications to aid in selecting bait application rates
}

\author{
Madeleine Pott ${ }^{\mathrm{a}, *}$, Alexander S. Wegmann ${ }^{\mathrm{a}}$, Richard Griffiths ${ }^{\mathrm{a}}$, Araceli Samaniego-Herrera ${ }^{\mathrm{b}, \mathrm{c}}$, \\ Richard J. Cuthbert ${ }^{\mathrm{d}, 1}$, M. de L. Brooke ${ }^{\mathrm{e}}$, William C. Pitt ${ }^{\mathrm{f}, 2}$, Are R. Berentsen ${ }^{\mathrm{g}}$, Nick D. Holmes ${ }^{\mathrm{a}}$, \\ Gregg R. Howald ${ }^{a}$, Karina Ramos-Rendón ${ }^{b}$, James C. Russell ${ }^{\mathrm{c}}$ \\ a Island Conservation, 2161 Delaware Avenue, Suite A, Santa Cruz, CA 95060, USA \\ ${ }^{\mathrm{b}}$ Grupo de Ecología y Conservación de Islas, Ensenada, Baja California, Mexico \\ 'School of Biological Sciences and Department of Statistics, University of Auckland, Private Bag 92019, Auckland, New Zealand \\ ${ }^{\mathrm{d}}$ Royal Society for the Protection of Birds, The Lodge, Sandy, Bedfordshire, United Kingdom \\ e Department of Zoology, University of Cambridge, Downing Street, Cambridge CB2 3EJ, UK \\ ${ }^{\mathrm{f}}$ USDA APHIS WS, National Wildlife Research Center, Hawaii Field Station, P.O. Box 10880, Hilo, HI 96721, USA \\ ${ }^{\mathrm{g}}$ USDA APHIS WS, National Wildlife Research Center, 4101 LaPorte Ave., Fort Collins, CO 80521-2154, USA
}

\section{A R T I C L E I N F O}

\section{Article history:}

Received 30 April 2014

Received in revised form 17 September 2014

Accepted 27 September 2014

Available online 6 November 2014

\section{Keywords:}

Rodent

Island

Conservation

Crab

Tropical

Eradication

\begin{abstract}
A B S T R A C T
Rodent eradications undertaken on tropical islands are more likely to fail than eradications undertaken at higher latitudes. We report on 12 independent rodent eradication projects undertaken on tropical islands that utilized the results of an in situ bait availability study prior to eradication to inform, a priori, the bait application rate selected for the eradication. These projects also monitored bait availability during the eradication. The results from our analysis verified the utility of bait availability studies to future rodent eradication campaigns and confirmed the influence of two environmental factors that can affect bait availability over time: precipitation prior to the study and the abundance of land crabs at the study site. Our findings should encourage eradication teams to conduct in-depth assessments of the targeted island prior to project implementation. However, we acknowledge the limitations of such studies (two of the projects we reviewed failed and one removed only one of two rodent species present) and provide guidance on how to interpret the results from a bait availability study in planning an eradication. Study design was inconsistent among the twelve cases we reviewed which limited our analysis. We recommend a more standardized approach for measuring bait availability prior to eradication to provide more robust predictions of the rate at which bait availability will decrease during the eradication and to facilitate future comparisons among projects and islands.
\end{abstract}

(c) 2014 Elsevier Ltd. All rights reserved.

\section{Introduction}

Despite adopting some of the most up-to-date and accepted eradication methods, rodent eradications undertaken on tropical islands are more likely to fail than eradications undertaken at higher latitudes (Russell and Holmes, 2015; Varnham, 2010). The more than twofold difference in failure rate (Russell and Holmes, 2015) suggests that the methods and strategies developed and

\footnotetext{
* Corresponding author. Tel.: +1 (831) 3594787.

E-mail address: madeleine.pott@islandconservation.org (M. Pott).

1 Wildlife Conservation Society, Goroka, Eastern Highlands Province, Papua New Guinea.

${ }^{2}$ Smithsonian Conservation Biology Institute, National Zoological Park, 1500 Remount Road, Front Royal, VA 22630, USA.
}

used in temperate ecosystems may not be wholly applicable to tropical environments (Keitt et al., 2015; Wegmann et al., 2011). The higher and more consistent year-round temperatures found on tropical islands contrast with conditions on temperate islands and will influence the perceived main factors that affect eradication success, such as rodent breeding behavior, the availability of natural food for rats, and non-target bait consumers (SamaniegoHerrera et al., 2014; Wegmann et al., 2011).

One response to the added complexity of tropical island rodent eradications has been the development and use of pre-eradication "bait availability" studies in situ. Using non-toxic versions of the rodent bait selected for the eradication, such studies test the proposed baiting strategy and assess the minimum amount of bait needed to achieve success (Brooke et al., 2010; Wanless et al., 2008). Bait availability is a measure of the density ( $\mathrm{kg} / \mathrm{ha}$ ) of rodent 
bait available to rodents at a point in time or over a period of time. It has been common practice to aim for four days of bait availability (Keitt et al., 2015), a recommendation stemming partially from the U.S. Environmental Protection Agency requirement for second generation anticoagulants to achieve 90\% efficacy within three days (Schneider, 1982).

The first published bait availability study occurred in 2004 on Little Barrier Island, New Zealand (Greene and Dilks, 2004). Henceforward, bait availability studies have been incorporated into the planning and implementation of several rodent eradication projects on tropical, temperate, subarctic, and sub-Antarctic islands. The Palmyra Atoll bait availability study (Buckelew et al., 2005) and a similar study conducted on Isabel Island, Mexico (Samaniego-Herrera et al., 2010) were undertaken because previous attempts to eradicate rats from these islands failed. In both cases, competition for bait by land crabs (Griffiths et al., 2011; Wegmann, 2008) and other factors unique to tropical islands were believed to have influenced the outcome. Subsequent campaigns were successful in eradicating rats from both of these sites, using baiting strategies developed through the use of preparatory bait availability studies. Other rodent eradication projects (both tropical and temperate) have employed similar studies to both shape the development of bait application strategies and to guide bait application rates during the implementation of eradication projects.

We report on 12 independent rodent eradication projects undertaken in the tropics that utilized the results of an in situ bait availability study prior to eradication to determine, a priori, the bait application rate selected for the eradication. All of these projects also monitored bait availability during the eradication, allowing us to assess how well such studies predict bait availability during an eradication campaign. The studies we examined were of varied design and execution. By comparing these results, we verify the utility of bait availability studies to future rodent eradication campaigns and investigate factors associated with bait availability over time. We also provide guidelines for the planning and standardization of future bait availability studies to assist with the interpretation of results and to facilitate future meta-analyses to improve the practice of eradicating invasive rodents from islands.

\section{Methods}

To verify the utility and generality of bait availability studies, we compared 12 rodent eradication projects for which: (1) a study conducted prior to the eradication was used to determine the final bait application rate used in the eradication attempt, (2) high quality raw data were available, and (3) practitioners were available for comment. These projects are presented in Table 1 along with key elements of the study designs used. Rodents (three species of rats: Rattus exulans, $R$. rattus, $R$. tanezumi, and one species of mouse: Mus musculus) were successfully eradicated in eight of the 12 projects; three projects were unsuccessful and the outcome for one has not been confirmed (Table 1). Eradications during which mice and rats were targeted were treated separately as there is evidence to suggest that fundamental differences in mouse and rat behavior may require different baiting strategies for individuals of each genus (MacKay et al., 2007).

Pre-eradication studies were conducted in an effort to identify the minimum application rate required to ensure that bait would remain available to the targeted rodent population for sufficient time, thus maximizing the chance of eradication success. In comparison, studies undertaken during the eradication aimed to document how long bait was available to the targeted population of rodents and to assess the accuracy (on-the-ground application rate and uniformity) of the bait application (Engeman et al., 2013). A non-toxic version of the rodenticide proposed for each eradication was used during pre-eradication studies. For the purposes of determining bait exposure in animals, all non-toxic versions also contained a biomarker (pyranine or Rhodamine B) detectable under ultraviolet light. There is, however, some evidence that biomarkers in baits can affect palatability in both mice and rats (Pitt, 2015; Weerakoon and Banks, 2011).

In most cases, the islands were too large to be baited in their entirety during the pre-eradication studies and smaller study sites were established. In the cases of Palmyra Atoll and Dekehtik Island, one or more small islets ( $<3 \mathrm{ha}$ ) were used as study sites and were baited entirely during the studies. Study sites on larger islands were situated in parts of the island that were readily accessible to personnel and, where necessary, were replicated in order to sample representative habitat types, as in the case of Wake Atoll (IC, 2013b; Wegmann et al., 2009) and Isabel Island (SamaniegoHerrera et al., 2010). The baited areas of study sites ranged from 0.26-20 ha. Fixed plots within study areas at Palmyra Atoll, Wake Atoll, Isabel Island, and Henderson Island were stratified by habitat type and randomly located (Berentsen et al., 2014; Cuthbert et al., 2012; Samaniego-Herrera et al., 2010; Wegmann et al., 2009). Plots were randomly located with no differentiation by habitat at the other study sites.

All bait applied to the pre-eradication study sites was broadcast by hand and bait application rates were based on knowledge of the environmental factors present at the site, e.g. the presence of land crabs, and information from other rodent eradications previously completed in similar environments. In the case of eradications, the aerial distribution of bait containing a rodenticide (Howald et al., 2007) was the primary method of bait application at all sites except Pohnpei (Wegmann et al., 2007), Pérez Island, Pájaros Island, Muertos Island (GECI, 2013), and Allen Cay (Alifano et al., 2012) where bait was applied by hand.

Following the application of bait to the study area, bait availability was measured in two ways: either counting the number of pellets remaining within plots or weighing pellets remaining within plots. Studies variously used fixed transect-lines, transectplots ( $1 \mathrm{~m}$ wide), or square-plots, where individual bait pellets applied at the target application rate were marked within a designated area and the presence of each pellet was noted daily throughout the study period. Bait pellets were marked with pin flags or chalk circles depending on the substrate at the study site. Other studies used fixed or randomly located circular plots in which pellets within a set distance from a central point were recorded daily throughout the study period. The random circle plots employed during the pre-eradication study at Palmyra consisted of large circles (radius $3 \mathrm{~m}$ ) centered on random points on the island which changed daily. The fixed circle plots used during the Palmyra eradication consisted of a PVC hoop (radius $0.68 \mathrm{~m}$ ) into which pellets were added or removed from the plot as needed to reflect the prescribed bait application rate (Berentsen et al. 2014). Bait availability within fixed circle plots (radius $3 \mathrm{~m}$ for both pre- and during-eradication studies) at Isabel, Muertos, Pájaros, Pérez, and Cayo Norte Mayor was assessed by collecting, weighing and returning all pellets to the corresponding plots.

The wide range of study designs employed by the 12 projects (Table 1) made it challenging to complete an analysis of the results. In several cases, the methods used to assess bait availability differed between the pre-eradication bait availability study and the study executed during project implementation. Several projects also measured bait availability during the eradication at sites that were different to those used in the pre-eradication study. Because the same sample days (days after bait was applied to the study area) and the number of sample days during which bait availability was measured were not consistent across the projects considered here, we were only able to compare measures of bait availability collected on sample days 1 and 3. 
Table 1

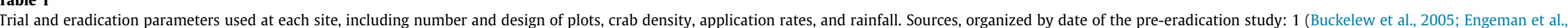

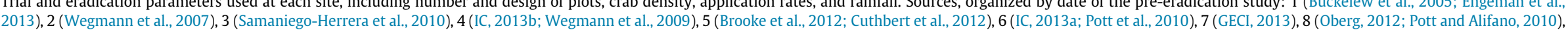

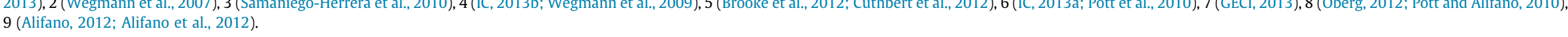

\begin{tabular}{|c|c|c|c|c|c|c|c|c|c|c|c|c|c|c|c|c|}
\hline \multicolumn{6}{|l|}{ Study site } & \multicolumn{3}{|c|}{$\begin{array}{l}\text { Sampling plan (pre- } \\
\text { eradication) }\end{array}$} & \multicolumn{3}{|c|}{$\begin{array}{l}\text { Sampling plan } \\
\text { (eradication) }\end{array}$} & \multicolumn{2}{|c|}{$\begin{array}{l}\text { Bait application rate }(\mathrm{kg} / \\
\text { ha) }\end{array}$} & \multicolumn{2}{|c|}{ Rainfall $(\mathrm{mm})^{\mathrm{e}}$} & \multirow[t]{2}{*}{ Source } \\
\hline $\begin{array}{l}\text { Site name (year of } \\
\text { pre-eradication } \\
\text { study) }\end{array}$ & $\begin{array}{l}\text { Latitude/ } \\
\text { longitude } \\
\text { (decimal } \\
\text { degrees) }\end{array}$ & $\begin{array}{l}\text { Eradication } \\
\text { area (ha) }\end{array}$ & $\begin{array}{l}\text { Eradication } \\
\text { outcome }^{\mathrm{b}}\end{array}$ & $\begin{array}{l}\text { Seasonal } \\
\text { timing of } \\
\text { studies }^{c}\end{array}$ & $\begin{array}{l}\text { Estimated } \\
\text { crab } \\
\text { density }\end{array}$ & Plot shape & $\begin{array}{l}\text { Plot } \\
\text { area } \\
\left(\mathrm{m}^{2}\right)\end{array}$ & $\begin{array}{l}\text { \# Of } \\
\text { plots }\end{array}$ & $\begin{array}{l}\text { Plot } \\
\text { shape }\end{array}$ & $\begin{array}{l}\text { Plot } \\
\text { area } \\
\left(\mathrm{m}^{2}\right)\end{array}$ & $\begin{array}{l}\text { \# Of } \\
\text { plots }\end{array}$ & $\begin{array}{l}\text { Pre- } \\
\text { eradication }\end{array}$ & Eradication $^{\mathrm{d}}$ & $\begin{array}{l}\text { Pre- } \\
\text { eradication }\end{array}$ & Eradication & \\
\hline $\begin{array}{l}\text { Palmyra Atoll } \\
\text { (2005) }\end{array}$ & $5.88 /-162.08$ & $235^{\mathrm{a}}$ & Success & Same & $\begin{array}{l}\text { Medium- } \\
\text { high }\end{array}$ & Circle & 28.3 & 35 & Circle & 1.4 & 40 & 95 & 80 & 573.19 & 25.65 & 1 \\
\hline $\begin{array}{l}\text { Dekehtik Island } \\
\text { (2007) }\end{array}$ & $6.84 / 158.32$ & $2.6^{\mathrm{a}}$ & Success & Same & $\begin{array}{l}\text { Medium- } \\
\text { high }\end{array}$ & Square & 25 & 10 & $\begin{array}{l}\text { Transect } \\
\text { plot }\end{array}$ & 50 & 9 & 45 & 50 & 31.83 & 27.17 & 2 \\
\hline $\begin{array}{l}\text { Isabel Island } \\
\text { (2009) }\end{array}$ & $21.84 /-105.88$ & 82 & Success & Different & None-low & Circle & 28.3 & 10 & Circle & 28.3 & 90 & 10 & 12 & 13.80 & 0.20 & 3 \\
\hline Wake Atoll (2009) & $19.28 / 166.64$ & 637 & Failure & Different & None-low & $\begin{array}{l}\text { Transect } \\
\text { plot and } \\
\text { circle }\end{array}$ & 50 & $\begin{array}{l}25, \\
25\end{array}$ & $\begin{array}{l}\text { Transect } \\
\text { plot }\end{array}$ & 25 & 18 & 18 & 18 & ${ }^{* *}$ & ** & 4 \\
\hline $\begin{array}{l}\text { Henderson Island } \\
\text { (2009) }\end{array}$ & $-24.22 / 128.3$ & 4,300 & Failure & Same & $\begin{array}{l}\text { Medium- } \\
\text { high }\end{array}$ & $\begin{array}{l}\text { Transect } \\
\text { line }\end{array}$ & - & 200 & $\begin{array}{l}\text { Transect } \\
\text { line }\end{array}$ & - & 200 & $20-60^{\mathrm{f}}$ & $10-60^{\mathrm{f}}$ & ** & $* *$ & 5 \\
\hline $\begin{array}{l}\text { Desecheo Island } \\
\quad(2010)\end{array}$ & $18.38 /-67.48$ & 120 & Failure & Same & $\begin{array}{l}\text { Medium- } \\
\text { high }\end{array}$ & Square & 25 & 10 & $\begin{array}{l}\text { Transect } \\
\text { plot }\end{array}$ & 25 & 5 & 18 & 18 & 19.05 & 224.28 & 6 \\
\hline $\begin{array}{l}\text { Pájaros Island } \\
\text { (2010) }\end{array}$ & $22.37 \mid-89.65$ & 3 & Success & Same & None-low & Circle & 28.3 & 20 & Circle & 28.3 & 15 & 15 & 12 & 130.64 & 112.35 & 7 \\
\hline $\begin{array}{l}\text { Pérez Island } \\
\text { (2010) }\end{array}$ & $22.38 /-89.68$ & 14 & Success & Same & None-low & Circle & 28.3 & 21 & Circle & 28.3 & 25 & 25 & 12 & 130.64 & 88.82 & 7 \\
\hline $\begin{array}{l}\text { Pinzón Island } \\
\text { (2010) }\end{array}$ & $-0.61 /-90.66$ & 1,904 & Unknown & Same & None-low & Square & 100 & 22 & $\begin{array}{l}\text { Transect } \\
\text { plot }\end{array}$ & 25 & 10 & 5.3 & 6.7 & 21.70 & 16.30 & 8 \\
\hline $\begin{array}{l}\text { Cayo Norte Mayor } \\
\text { (2010) }\end{array}$ & $18.74 /-87.3$ & 29 & Success & Same & $\begin{array}{l}\text { Medium- } \\
\text { high }\end{array}$ & Circle & 28.3 & 15 & Circle & 28.3 & 20 & 50 & 30 & 130.50 & 35.40 & 7 \\
\hline $\begin{array}{l}\text { Muertos Island } \\
\text { (2011) }\end{array}$ & $22.42 /-89.72$ & 15 & Success & Different & None-low & Circle & 28.3 & 30 & Circle & 28.3 & 28 & 15 & 12 & 0.68 & 91.02 & 7 \\
\hline Allen Cay (2011) & $27.74 /-76.83$ & 6 & Success & Different & None-low & $\begin{array}{l}\text { Transect } \\
\text { plot }\end{array}$ & 10 & 10 & $\begin{array}{l}\text { Transect } \\
\text { plot }\end{array}$ & 10 & 12 & 20 & 20 & 12.96 & 13.39 & 9 \\
\hline
\end{tabular}

a Key: Pre-eradication study was performed on a smaller, neighboring or component island with similar habitat.

Success: rodents absent from island $1+$ years from eradication; failure: rodent population persists subsequent to eradication.

c Eradication conducted in the same calendar month as pre-eradication study ( \pm 1 month).

${ }^{\mathrm{d}}$ Density of bait applied during the first application.

Average monthly rainfall recorded during the three months prior to each study.

${ }^{f}$ A range of bait densities, dependent on habitat type and crab abundance, were applied.

No rainfall data were available for these sites. 
Nevertheless, to identify trends within the data set that might be useful for future rodent eradication projects, we constructed a linear mixed model ( $\mathrm{R}$ software package nlme) for bait availability where the density of bait $(\mathrm{kg} / \mathrm{ha})$ was dependent on time (days) and interactions of time with fixed effect covariates (i.e. covariates which would affect bait availability). These fixed effects included whether the study was conducted prior to the eradication or during the eradication, whether rats or mice were the target species, the success or failure of the eradication, the abundance of land crabs (none - low or medium - high, based on the practitioner's assessment), the average monthly rainfall for three months prior to the pre-eradication or eradication study (using either data collected on-site, data collected locally by a government or institution, or data collected from NCDC NOAA, in that order), and study plot geometry (circle, square or transect-plot). We excluded Henderson Island and Wake Atoll from the analysis because raw data were not available from the pre-eradication study and because no rainfall data were available, respectively. Our random effects captured the nested design of the studies with bait availability plots nested in islands. Bait availability $(\mathrm{kg} / \mathrm{ha})$ was $\log _{10}(-$ $x+1)$ transformed and rainfall values were $\log _{10}(x)$ transformed for normality. Although each island used different prior rates of bait application, we were specifically interested in the rates of decline in bait availability and account for inter-island differences by the random effect for island in our model. Diagnostic plots were visually checked for violations of model assumptions.

\section{Results}

For nine of the 12 projects assessed, studies conducted prior to the eradication project yielded bait availability estimates that were within $20 \%$ of the bait availability estimates obtained from the studies conducted during the eradication projects (Table 2); values for four or more days after the bait application were not available from all 12 projects. From an exploration of the data, we were not able to explain why some studies were more predictive than others. It is possible that study design influenced the capacity of the pre-eradication study to predict the bait availability result for the eradication. For instance, the pre-eradication study and the eradication for the Allen Cay and Muertos Island projects were undertaken at different times of year (Table 1). Seasonal influences on Allen Cay and Muertos Island could have been the reason why the pre-eradication studies underestimated bait availability during the eradication by $39 \%$ and $19 \%$, respectively, on the first day and by $44 \%$ and $45 \%$ on the third day, respectively (Table 2 ). However, the overall predictive ability of pre-eradication studies was supported by our linear mixed model that found no significant difference between the rate of decrease in bait availability depending on study type (pre-eradication or eradication) (Table 3; Fig. 1a).

Our linear mixed model determined several factors and interactions between factors that influenced bait availability (Table 3). As expected, bait availability decreased over time. Bait availability was slightly greater during pre-eradication studies than during the eradications (Fig. 1a). Higher bait application rates were used during six of 12 pre-eradication studies to ensure that bait would be available for long enough to identify the desired bait application rate for the eradication. Similarly, more bait was applied at sites with greater rainfall in the three-month period leading up to bait availability studies both prior to and during eradication projects (Table 3). This finding presumably arises from the concern that bait pellets degrade more quickly when exposed to moisture and because higher rainfall may lead to greater resource availability to rats (Berentsen et al., 2014; Morriss et al., 2008).

Our model also showed that several interacting factors influenced the rate at which bait availability declined over time (Table 3). Bait availability was exhausted sooner at sites where the eradication failed (study day $\times$ outcome) (Table 3; Fig. 1b). Bait availability declined more rapidly at sites: that had a higher density of land crabs (study day $\times$ estimated crab density) (Fig. 1c), where rainfall was greater, (study day $\times$ rainfall three months prior to the study), and where transect-plots, instead of circle or square plots, were used to measure bait availability (study day $\times$ study method) (Table 3 ). Bait availability was similar for projects targeting Rattus spp. and M. musculus even though bait application rates were slightly higher for Rattus projects than for M. musculus projects (Fig. 1d).

\section{Discussion}

For rodent eradication projects that face novel or poorly understood environmental factors, on tropical islands for instance (Samaniego-Herrera et al., 2014; Wegmann et al., 2011), it is risky to base bait application rates solely on experience of temperate or sub-Antarctic islands (Howald et al., 2007; Towns and Broome,

Table 2

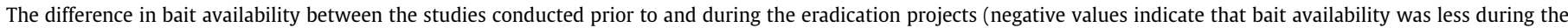

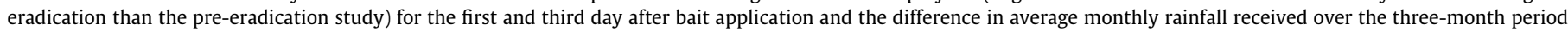

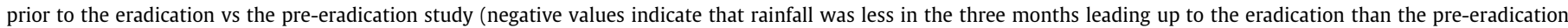
study).

\begin{tabular}{|c|c|c|c|}
\hline \multirow[t]{2}{*}{ Site name } & \multicolumn{2}{|c|}{$\begin{array}{l}\text { Percent change in bait availability: eradication vs the } \\
\text { pre-eradication study }\end{array}$} & \multirow[t]{2}{*}{$\begin{array}{l}\text { Rainfall }(\mathrm{mm}) \text { received within the preceding three months: } \\
\text { eradication minus pre-eradication study }\end{array}$} \\
\hline & $\begin{array}{l}1 \text { day after bait } \\
\text { application }\end{array}$ & $\begin{array}{l}3 \text { days after bait } \\
\text { application }\end{array}$ & \\
\hline Palmyra Atoll & -14 & 5 & -547.5 \\
\hline Dekehtik Island & 33 & 36 & -4.7 \\
\hline Isabel Island & 20 & 9 & -13.6 \\
\hline Wake Atoll & -8 & -8 & $*$ \\
\hline $\begin{array}{l}\text { Henderson } \\
\text { Island }\end{array}$ & 1 & 25 & $*$ \\
\hline Desecheo Island & 20 & 4 & 205.2 \\
\hline Pájaros Island & 48 & 42 & -18.3 \\
\hline Pérez Island & -1 & 17 & -41.8 \\
\hline Pinzón Island & 10 & -12 & -5.4 \\
\hline $\begin{array}{l}\text { Cayo Norte } \\
\text { Mayor }\end{array}$ & 17 & 16 & -95.1 \\
\hline Muertos Island & -19 & -45 & 90.3 \\
\hline Allen Cay & -39 & -44 & 0.4 \\
\hline
\end{tabular}

* No rainfall data available. 
Table 3

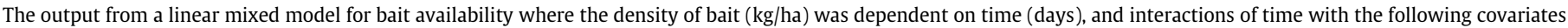

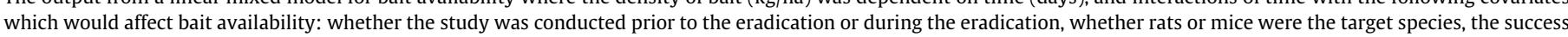

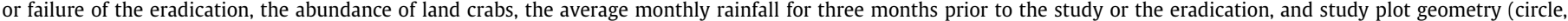
square or transect).

\begin{tabular}{|c|c|c|c|}
\hline Parameters & Value & SE & $P$ \\
\hline \multicolumn{4}{|l|}{ Factors } \\
\hline Intercept & 0.972 & 0.431 & $0.024^{*}$ \\
\hline Study day & -0.174 & 0.025 & $<0.001^{*}$ \\
\hline Study type (eradication) & -0.184 & 0.429 & $<0.001^{*}$ \\
\hline Genus (Rattus) & 0.105 & 0.26 & 0.715 \\
\hline Outcome (success) & 0.292 & 0.386 & 0.504 \\
\hline Estimated crab density (medium-high) & 0.435 & 0.261 & 0.195 \\
\hline Rainfall three months prior to the study $\left(\log _{10}\right)$ & -0.075 & 0.316 & $0.018^{*}$ \\
\hline Study method (square) & 0.111 & 0.327 & 0.756 \\
\hline Study method (transect) & 0.14 & 0.326 & 0.698 \\
\hline \multicolumn{4}{|l|}{ Interactions } \\
\hline Study day $\times$ study type (eradication) & 0.005 & 0.008 & 0.546 \\
\hline Study day $\times$ genus (Rattus) & 0.003 & 0.01 & 0.736 \\
\hline Study day $\times$ outcome (success) & 0.768 & 0.024 & $0.001^{*}$ \\
\hline Study day $\times$ estimated crab density (medium-high) & -0.057 & 0.01 & $<0.001 *$ \\
\hline Study day $\times$ rainfall three months prior to the study $\left(\log _{10}\right)$ & -0.01 & 0.004 & $0.011^{*}$ \\
\hline Study day $\times$ study method (square) & 0.029 & 0.016 & 0.081 \\
\hline Study day $\times$ study method (transect) & -0.061 & 0.014 & $<0.001^{*}$ \\
\hline
\end{tabular}
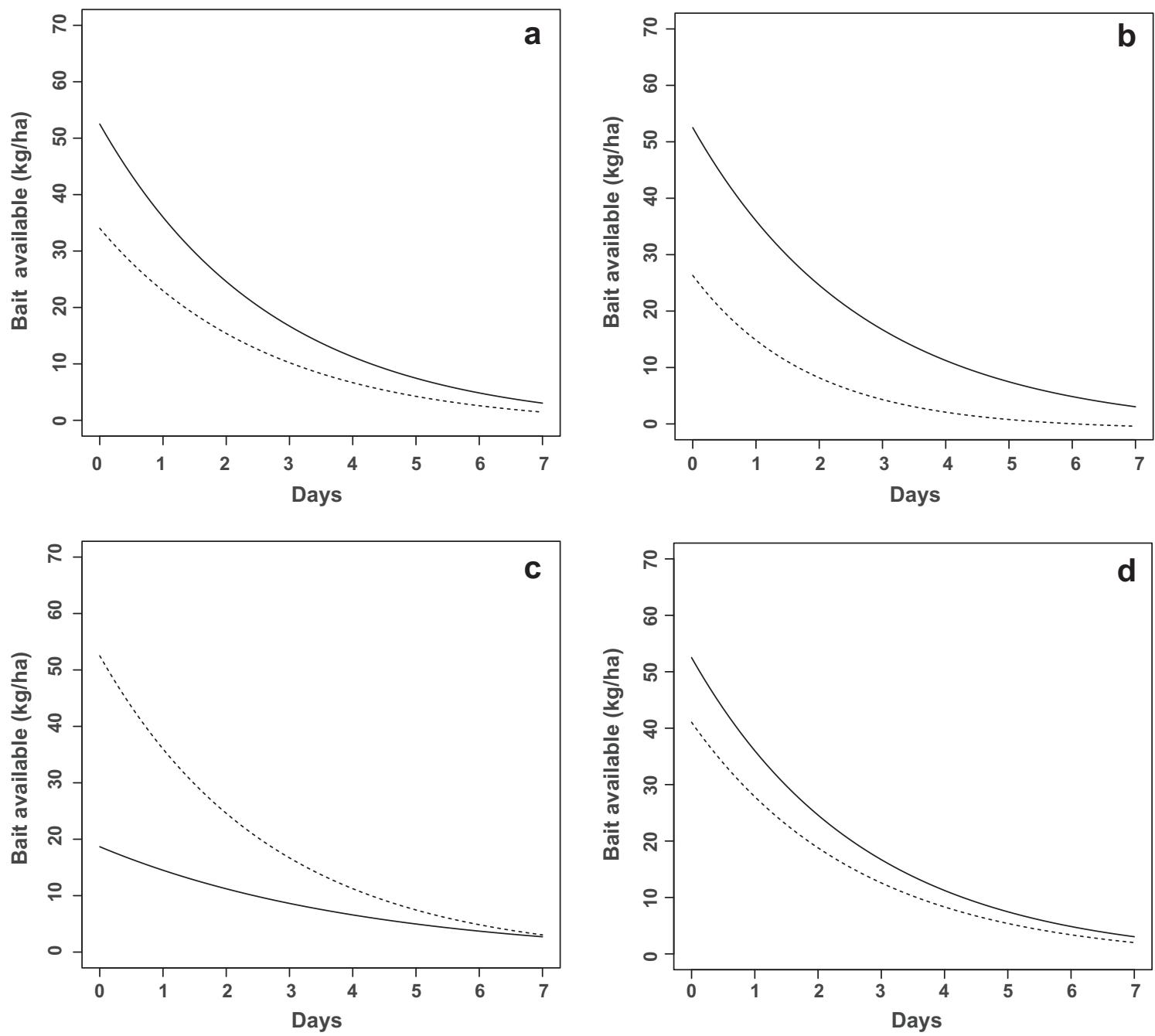

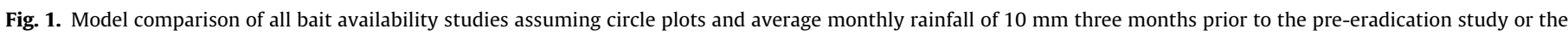

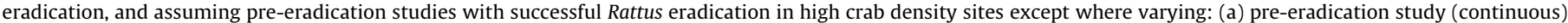
vs eradication (dashed), (b) successful (continuous) vs failed (dashed), (c) low (continuous) vs high (dashed) density crabs, (d) Rattus (continuous) vs Mus (dashed). 
2003). Non-target bait consumers such as land crabs (Brooke et al., 2012; Griffiths et al., 2011) and the degradation of bait caused by warm, wet topical conditions (Berentsen et al., 2014) can rapidly reduce bait availability which, compounded by widely available competing food resources (Weerakoon and Banks, 2011), can increase the probability that some rodents could escape lethal exposure to the rodenticide, essentially ensuring eradication failure.

Our results confirm the importance of these factors with both rainfall and the density of land crabs influencing bait availability over time in the studies we reviewed. Our model also suggested that bait availability over time influenced whether or not an eradication project was successful. The reduced success rate for rodent eradications on tropical islands (Holmes et al., 2015) and the recent failure of several tropical island rodent eradications highlight the potential consequences of such a scenario. Inadequate bait availability was considered to be a potential cause of failure for several of these projects (Brown et al., 2013; Brown and Tershy, 2013), although bait was reported to be on the ground for more than 25 days after the operation in some failed eradications. Such observations suggest that factors beyond bait availability may influence the outcome of rodent eradications undertaken on tropical islands (i.e. where natural food sources are preferred over rodent baits) (Brown et al., 2013; Brown and Tershy, 2013).

That greater bait availability over time increased the likelihood that an eradication project would succeed is a logical conclusion; increased bait availability results in increased opportunities for rodents to encounter and consume bait. This finding should not be interpreted as support for higher than necessary bait application rates for rodent eradication projects, particularly in light of the risks to non-target species (Eason and Ogilvie, 2009; Fisher, 2009; Pitt et al., 2015). Rather, we suggest that measuring bait availability over time prior to a rodent eradication will help the implementation team determine a project-specific bait application rate that maximizes the probability of successfully eradicating rodents from the island, while reducing the risk of exposing nontarget species to the rodenticide.

Direct competition by land crabs for bait also necessitates a bait application rate that exceeds the base quantity required to eradicate the targeted population of rodents (Brooke et al., 2010; Wegmann, 2008; Wegmann et al., 2012). The impact of land crabs on bait availability led to a decision to apply bait at approximately $160 \mathrm{~kg} /$ ha over two applications at Palmyra Atoll; the baiting strategy was adjusted according to data obtained during pre-eradication bait availability studies (Wegmann et al., 2012).

The setting of bait application rates should also take into account potential harm to non-target species. During the eradication, all reasonable and prudent efforts should be made to minimize bait consumption by non-target species. On tropical islands where precipitation is highly seasonal, the impacts of land crab interference can be addressed if the eradication is completed during periods of reduced crab activity, usually the driest period of the year (Samaniego-Herrera and BedollaGuzman, 2012; Samaniego-Herrera et al., 2014). While the life history of land crabs does not allow for significant, intra-annual shifts in abundance, weather patterns (cloud cover and precipitation) can affect the degree to which land crabs influence bait availability by changing crab activity patterns (Burggren and McMahon, 1988).

Bait exposure studies are oftentimes conducted in conjunction with bait availability studies through the use of a bait product containing a biomarker e.g., pyranine, Rhodamine B, or tetracycline, to assess the exposure of potential target and non-target bait consumers to bait (Cuthbert et al., 2012; Greene and Dilks, 2004; Pott and Alifano, 2010; Spurr, 2002; Wegmann et al., 2008). These studies address a fundamentally different question: What proportion of a population was exposed to bait with a specified bait application strategy? Bait exposure trials are recommended when it is suspected that one or more aspects of the island's environment could cause the target rodent population(s) to not consume bait even when the desired bait availability is achieved (e.g. Wanless et al., 2008) or when exposure to non-target species is suspected (e.g. Greene and Dilks, 2004). Target animals are trapped and assessed for exposure to bait while bait availability is measured within the study plots. Bait containing pyranine brings an added advantage to bait availability studies over other compounds: while pyranine is invisible to the naked eye in daylight, under low light conditions, and when exposed to ultraviolet light, it fluoresces bright green. This quality assists in locating bait pellets within a sample plot or the surrounding environment. However, as a water soluble compound, pyranine persists in the digestive system of rodents for as little as three days before being excreted and becoming undetectable in rodents (Wegmann et al. 2008).

To improve standardization and improve prospects of success for future rodent eradication projects on tropical islands, we recommend bait application rates that allow for a minimum of four nights of bait availability, meaning that bait will still be available to rats through the fourth night following bait application. We base this in part on laboratory trials which demonstrated three-day choice trials with second generation anticoagulant baits were insufficient to achieve $100 \%$ mortality in rats (Pitt et al., 2011) and studies which have shown food intake by Norway rats $(R$. norvegicus) to require one to two days to stabilize after encountering novel food items (Barnett, 1958). Bait application rates must also account for individual rodent vulnerability due to age, behavior, body size, food supply, and range size, as recommended by Cromarty et al. (2002). Given these conditions and behaviors, at least four nights of bait availability is recommended to ensure that all individual rodents in the population will consume a lethal dose of rodenticide.

Measuring bait availability prior to a rodent eradication project can provide an accurate prediction of the rate at which bait will disappear during an actual eradication, as demonstrated by nine of 12 sites where estimates for study and eradication conditions fell within $20 \%$ of each other. Furthermore, when the environmental factors influencing bait availability are better understood, the utility of measuring bait availability can be maximized by conducting the pre-eradication study at a time when these factors will be similar to those anticipated during the eradication. The significant interactions between factors such as rainfall, land crabs, and bait availability support this recommendation. These findings should encourage eradication teams to conduct in-depth assessments of the targeted island prior to project implementation, ideally in conjunction with other project-specific investigations relating to rodent biology (Russell et al., 2015) and risk to non-target species (Brooke et al., 2013; Pitt et al., 2015).

We recognize there is a limitation to the utility of studies that measure bait availability prior to and during an eradication project. The fact that pre-eradication studies accurately predicted bait availability trends for two unsuccessful projects and Wake Atollwhere only one of two rat species was eradicated-highlights the need for a reassessment of the way results from bait availability studies are interpreted. Previously, mean bait availability over time was used to guide a decision on the bait application rates for an eradication operation. For future projects, we believe application rates are best calculated using a $99 \% t$-statistic confidence interval. The lower-limit of the $99 \% \mathrm{CI}$ provides a suitably conservative estimate of bait availability, provided that sample size is sufficient and appropriate given the habitat structure of the island. If bait availability is predicted to decline rapidly within a specific region or habitat on the island, the lowest estimate of bait availability over 
four days and across all study plots within that region or habitat can also be used to determine the bait application rate for the eradication.

It may be impractical or undesirable to stratify bait application rates during the eradication (Keitt et al., 2015). Limiting sampling to an area or habitat that is predicted to yield the lowest estimate of bait availability hinges on an in-depth knowledge of the island and a robust study design to ensure that outlier values are not biasing the selection of a bait application rate for the eradication project.

It is also unrealistic to expect conditions during the pre-eradication assessment to always match those experienced during the eradication. Levels of precipitation can vary from year to year and can be difficult to predict in the months leading up to an eradication. We collected rainfall for the first five days of each study but this was tightly correlated with rainfall over three months prior and so we analyzed only the latter. Unfortunately, rainfall data were not available for two of three failed eradications and the one failed eradication for which data were available saw much greater precipitation during the eradication than during the earlier study period. Elevated rainfall likely contributes to primary productivity and available food resources and has been identified as a potentially influential factor on the outcome of several unsuccessful rodent eradications for which pre-eradication bait availability studies were conducted (Brown et al., 2013; Brown and Tershy, 2013).

As with any technique in early development, study design was not consistent between the 12 cases presented here; in many instances it was inconsistent between the pre-eradication study and the eradication (Table 1). Despite differences in study design, the rates of bait availability measured by pre-eradication studies were not significantly different from those measured during the eradications (Table 3). This finding suggests that a variety of methods can provide a reasonable estimate for determining bait application rates for an eradication operation. However, because the design of bait availability studies (plot geometry) did influence the measure of bait availability (Table 3), we encourage the adoption of a novel and standardized approach for measuring bait availability. It was assumed that the hardware (pin flags) or other marking techniques (chalk) did not influence bait availability, though this assumption warrants further study.

Standardizing future bait availability studies will provide more robust predictions of the rate at which bait availability will decrease during the eradication and will facilitate comparison with other studies, allowing conservation practitioners to gain a better understanding of tropical environments and how they influence rodent eradication success. The following recommendations on how to conduct bait availability studies reflect the results of the analysis and our accumulated experience; assessment of future bait availability studies will further refine the practice and enhance its service to rodent eradication projects worldwide.

\subsection{Recommendations for future bait availability studies}

1. Bait availability studies should be designed to identify the minimum values of bait availability. Consequently, study plots should occur in all representative habitats across the island or, at a minimum, in areas where the highest bait consumption by rodents and non-target consumers is expected. The baited study area should be large enough to mitigate for edge effect and provide an adequate buffer between the edge of the study site and sampling plots.

2. In an eradication, an application rate that provides a minimum of four nights of bait availability should be used to ensure that rodents anywhere on the island still have access to bait on the fourth night following bait application. This means that conservation practitioners should "overshoot" the anticipated application rate during the pre-eradication bait availability study to ensure that bait availability can be measured over four nights. Non-target bait consumers, especially land crabs (Griffiths et al., 2011; Wegmann, 2008), and baiting strategies used in previous eradication projects should be taken into account when selecting a bait application rate for a bait availability study.

3. The bait used in the pre-eradication bait availability study should be a non-toxic version of the bait that will be applied during the eradication.

4. An assessment of both meteorological factors (precipitation and percent cloud cover, especially on islands with crabs) and natural food availability (fruits, insects, etc.) should be conducted concurrent with the pre-eradication study to allow for a comparison with conditions experienced during the implementation of the eradication.

5. The pre-eradication study should be undertaken at the eradication site, at the same time of year as is planned for the eradication. Keep in mind that environmental factors (rainfall, availability of natural food items, non-target bait consumers) encountered during the year of the preeradication study may not always mimic conditions prevailing during the eradication year. An in-depth knowledge of the factors influencing bait availability on the targeted island will allow better alignment of the timing of the preeradication study with the actual eradication.

6. The location of sample plots within the study site(s) should be stratified across the different habitat types sampled and randomly located within each stratum. If only one habitat type is present at the study site, then randomly place the plots throughout the site.

7. Establish and sample as many plots as possible; aim for a minimum of 30 plots to accommodate between-plot variation in bait availability measurements.

8. Sample each plot every day for at least 7 days or until all, or even most plots, have no bait remaining.

9. The study sites should be the same for both the pre-eradication study and the eradication. However, it is often desirable to measure bait availability across the entire island during the eradication and not just at the site used for the preeradication study.

10. Because of the inherent patchiness in the density of bait surrounding the study plots, the density of bait consumers, and probably other factors, estimates of bait availability are plagued by high variance. The design of bait availability study plots should be such that replication is maximized and the influence of patchiness on the estimate of bait availability is minimized. Long transect-plots $\left(25-50 \mathrm{~m}^{2}\right)$ will be less influenced by patchiness than fixed circle or square plots with smaller perimeter-to-area ratios. Small $\left(1 \mathrm{~m}^{2}\right)$, randomly placed circle plots, although more affected by this issue, are efficient to sample; the influence of patchiness can be overcome by increasing sample sizes and sampling over a larger portion of the study site. Ultimately, the characteristics of the study site (e.g. open or forested) and the availability of resources will dictate plot design.

11. On dry islands where moisture (rainfall, dew, ambient humidity) will not be absorbed by rodent bait, the amount of bait present within plots can be determined by weighing (and then returning) bait pellets. On islands where it is likely that pellets will absorb moisture, the number of pellets within each plot should be counted. Pellets that have been partially consumed or broken down should be graded for percentage remaining to the nearest $25 \%$. 


\section{Acknowledgments}

All authors designed and performed their respective studies. MP had full access to data used in the study and takes responsibility for the accuracy of its tabulation. NDH and JCR designed and performed the analyses of the data. ASW, MP, RG, and NDH wrote the manuscript. The National Fish and Wildlife Foundation (NFWF) and the David and Lucile Packard Foundation supported the writing of this effort. The views and conclusions contained in this document are those of the authors and should not be interpreted as representing the opinions or policies of NFWF. Mention of trade names or commercial products does not constitute their endorsement by NFWF. All authors reviewed and revised drafts of the manuscript.

Thanks to GECI, IC, RSPB, and USDA for making the bait availability data available for analysis. Thanks also to all landowners and partners who made these projects possible, including: U.S. Fish \& Wildlife Service (USFWS), U.S. Air Force, The Nature Conservancy, Parque Nacional Galápagos, Conservation Society of Pohnpei and the Municipality of Madolenihmw, and the Commonwealth of the Bahamas. We have The Nature Conservancy, Charles Darwin Foundation, INIFAP (Mexico), and the NCDC of NOAA to thank for collecting and making climatological data available. Island Conservation and its partners are grateful for the years of philanthropic support provided by its many donors and funders. The list of those who provided support is too long to present here, but all are acknowledged in our annual and impact reports, dating back to 2004-2005, which can be found at: http://www.islandconservation.org/about/?id=37. All projects on Mexican islands (Cayo Norte Mayor, Isabel, Muertos, Pájaros and Pérez) were planned and implemented by Grupo de Ecología y Conservación de Islas (GECI) and mainly funded by The David and Lucile Packard Foundation, Marisla Foundation, Fundación Carlos Slim - WWF México, USFWS and NFWF, with valuable in kind support from the Mexican Government (SEMAR, SEGOB, SEMARNAT, CONANP, CONABIO and INECC). A.S.-H. thanks CONACYT for the doctoral scholarship and WWF for the EFN fellowship. The Henderson Project was supported by the UK Government, the UK Overseas Territories Environment Programme and the David \& Lucile Packard Foundation, administered by the RSPB through the untiring dedication of Kathy Berkery, Geoff Hilton and Juliet Vickery. The Pitcairn community generously supported the conservation work, as did the crews of MVs Braveheart, Claymore and Aquila. The work on Henderson would not have been possible without the generous help of private donors, especially Susan Orr.

\section{References}

Alifano, A., 2012. Restoration of Allen Cay: a feasibility assessment for the removal of mice, Unpublished technical report, Island Conservation, Santa Cruz, CA, USA, p. 35 .

Alifano, A., Jolley, W., Griffiths, R., 2012. Final operational report for the removal of introduced house mice from Allen Cay, Exuma Islands, Bahamas. Unpublished technical report, Island Conservation, Santa Cruz, CA, USA, p. 19.

Barnett, S.A., 1958. Experiments on 'Neophobia' in wild and laboratory rats. Br. J. Psychol. 49, 195-201.

Berentsen, A.R., Pitt, W.C., Eisemann, J.D., Engeman, R.M., 2014. Longevity of rodenticide bait pellets in a tropical environment following a rat eradication program. Environ. Sci. Pollut. Res. 21, 2283-2288.

Brooke, M. de L., Cuthbert, R., Henricson, A., Torr, N., Warren, P., O’Keefe, S., 2010. Towards rat eradication on Henderson Island fieldwork report, AugustSeptember 2009. Unpublished Report to the Royal Society for the Protection of Birds, Sandy, Bedfordshire, UK, p. 49.

Brooke, M. de L., Harrison, G., Cuthbert, R.J., 2012. The Capture, Husbandry and Captive Breeding of Henderson Rails During the Henderson Island Rat Eradication and the Impact of the Project on Native Landbirds. Unpublished Report to the Royal Society for the Protection of Birds, Sandy, Bedfordshire, UK, p. 38.

Brooke, M. de L., Cuthbert, R.J., Harrison, G., Gordon, C., Taggart, M.A., 2013. Persistence of brodifacoum in cockroach and woodlice: implications for secondary poisoning during rodent eradications. Ecotoxicol. Environ. Saf. 97, 183-188.
Brown, D., Tershy, B., 2013. Unpublished report to Island Conservation: A review of the Desecheo Island rat eradication project, Island Conservation, Santa Cruz, CA, USA, p. 38.

Brown, D., Pitt, W., Tershy, B., 2013. Unpublished report to Island Conservation: Wake atoll rat eradication review, Island Conservation, Santa Cruz, CA, USA, p. 51.

Buckelew, S., Howald, G.R., Wegmann, A., Sheppard, J., Curl, J., McClelland, P., Tershy, B., Swift, K., Campbell, E., Flint, B., 2005. Progress in Palmyra Atoll restoration: rat eradication trial, 2005. Unpublished technical report, Island Conservation, Santa Cruz, CA, USA, p. 50.

Burggren, W.W., McMahon, B.R. (Eds.), 1988. Biology of the Land Crabs. Cambridge University Press, Cambridge, UK.

Cromarty, P.L., Broome, K.G., Cox, A., Empson, R.A., Hutchinson, W.M., McFadden, I., 2002. Eradication planning for invasive alien animal species on islands - the approach developed by the New Zealand Department of Conservation. In: Veitch C.R., Clout, M.N. (Eds.), Turning the Tide: the Eradication of Invasive Species. IUCN SSC Invasive Species Specialist Group, Gland, Switzerland, pp. 85-91.

Cuthbert, R.J., Brooke, M. de L., Torr, N., 2012. Overcoming hermit-crab interference during rodent-baiting operations: a case study from Henderson Island, South Pacific. Wildlife Res, 39, 70-77.

Eason, C.T., Ogilvie, S., 2009. A re-evaluation of potential rodenticides for aerial control of rodents. DOC Research and Development Series 312. Department of Conservation, Wellington, New Zealand, p. 33.

Engeman, R.M., Pitt, W.C., Berentsen, A.R., Eisemann, J.D., 2013. Assessing spatial variation and overall density of aerially broadcast toxic bait during a rat eradication on Palmyra Atoll. Environ. Sci. Pollut. Res. 20, 480-487.

Fisher, P., 2009. Residual Concentrations and Persistence of the Anticoagulant Rodenticides Brodifacoum and Diphacinone in Fauna. Unpublished doctoral thesis, Lincoln University, p. 151.

GECI, 2013. Ecological restoration of priority seabird nesting Islands: Arrecife Alacranes National Park \& Banco Chinchorro Biosphere Reserve. Unpublished technical report, Grupo de Ecología y Conservación de Islas, Ensenada, B.C. México, p. 32.

Greene, T.C., Dilks, P.K., 2004. Effects of a non-toxic bait application on birds. DOC Science Internal Series 175. Department of Conservation, Lincoln, New Zealand, p. 19.

Griffiths, R., Miller, A., Climo, G., 2011. Addressing the impact of land crabs on rodent eradications on islands. Pacific Conservation Biol. 17, 347-353.

Holmes, N.D., Griffiths, R., Pott, M., Alifano, A., Will, D., Wegmann, A.S., Russell, J.C. 2015. Factors associated with rodent eradication failure. Biol. Conserv. 185, 8-16.

Howald, G., Donlan, C.J. Galván, J.-P., Russell, J.C., Parkes, J., Samaniego, A., Wang, Y. Veitch, D., Genovesi, P., Pascal, M., Saunders, A., Tershy, B., 2007. Invasive rodent eradication on islands. Conserv. Biol. 21, 1258-1268.

IC, 2013a. Desecheo Island restoration project, operational report. Unpublished technical report to the U.S. Fish and Wildlife Service Caribbean Islands National Wildlife Refuge Complex, Island Conservation, Santa Cruz, CA, p. 83.

IC, 2013b. Wake Atoll rodent eradication project: post-operational report Unpublished technical report, Island Conservation, Santa Cruz, CA, USA, p. 49.

Keitt, B., Griffiths, R., Boudjelas, S., Broome, K., Cranwell, S., Millett, J., Pitt, W. Samaniego-Herrera, A., 2015. Best practice guidelines for rat eradication on tropical islands. Biol. Conserv. 185, 17-26.

MacKay, J.W., Russell, J.C., Murphy, E.C., 2007. Eradicating house mice from islands: successes, failures and the way forward. In: Witmer, G. W.; Pitt, W. C.; Fagerstone, K. A. (eds.) Managing Vertebrate Invasive Species: Proceedings of an International Symposium. USDA/APHIS/WS, National Wildlife Research Center, Fort Collins, CO, USA, p. 294-304.

Morriss, G.A., O'Connor, C.E., Airey, A.T., Fisher, P., 2008. Factors influencing palatability and efficacy of toxic baits in ship rats, Norway rats and house mice. Science for Conservation 282, Department of Conservation Wellington, New Zealand, p. 26.

Oberg, E., 2012. Pinzon bait availability report: November 7-December 19, 2012 Unpublished technical report, Island Conservation, Santa Cruz, CA, USA, p. 4.

Pitt, W., Driscoll, L., Sugihara, R., 2011. Efficacy of rodenticide baits for the control of three invasive rodent species in Hawaii. Arch. Environ. Contam. Toxicol. 60 533-542.

Pitt, W.C., Berentsen, A.R., Shiels, A.B., Volker, S.F., Eisemann, J.D., Wegmann A.S Howald, G.R., 2015. Non-target species mortality and the measurement of brodifacoum rodenticide residues after a rat (Rattus rattus) eradication on Palmyra Atoll, tropical Pacific. Biol. Conserv. 185, 36-46.

Pott, M., Alifano, A., 2010. Pinzon Island rat eradication: biomarker validation of an effective bait application rate and evaluation of non-target impacts. Unpublished technical report, Island Conservation, Santa Cruz, CA, USA, p. 10.

Pott, M., Swinnerton, K., McKown, M., Giraldo, J.L.H., 2010. Planning trip to Desecheo Island, Puerto Rico, to evaluate feasibility of rodent eradication, and further establish baseline biodiversity surveys: February 26-March 11, 2010 Unpublished technical report, Island Conservation, Santa Cruz, CA, USA, p. 44.

Russell, J.C., Holmes, N.D., 2015. Tropical island conservation: rat eradication for species recovery. Biol. Conserv. 185, 1-7.

Russell, J.C., Caut, S., Anderson, S.H., Lee, M., 2015. Invasive rat interactions and over-invasion on a coral atoll. Biol. Conserv. 185, 59-65.

Samaniego-Herrera, A., Bedolla-Guzman, Y., 2012. Land crabs (Decapoda, Brachyura, Gecarcinidae) on Isabel Island, Mexico, including a new record, and its relation to the removal of invasive rats. Crustaceana 85, 1007-1011.

Samaniego-Herrera, A., Rodríguez Malagón, M., Aguirre Muñoz, A., González Gómez, R., Torres García, F., Latofski Robles, M., Méndez Sánchez, F., Soqui Gómez, E., Silva Estudillo, N., 2010. Erradicación de rata negra en isla Isabel, México. Reporte Técnico. Grupo de Ecología y Conservación de Islas, Ensenada, B.C., México, p. 42. 
Samaniego-Herrera, A., Russell, J.C., Choquenot, D., Aguirre-Muñoz, A., Clout, M.N. 2014. Invasive rodents on tropical islands: eradication recommendations from Mexico. In: Timm, R.M. (Ed.), Proc. 26th Vertebrate Pest Conference. University of California, Davis (in press).

Schneider, B., 1982. Pesticide Assessment Guidelines. 540/g-82-026. U.S. Environmental Protection Agency, Washington, D.C.

Spurr, E.B., 2002. Rhodamine B as a systemic hair marker for assessment of bait acceptance by stoats (Mustela erminea). New Zealand J. Zool. 29, 187-194.

Towns, D.R., Broome, K.G., 2003. From small Maria to massive Campbell: forty years of rat eradications from New Zealand islands. New Zealand J. Ecol. 30, 377-398.

Varnham, K., 2010. Invasive Rats on Tropical Islands: Their History, Ecology, Impacts and Eradication. Royal Society for the Protection of Birds Conservation Science Department, Sandy, Bedfordshire, UK, p. 54.

Wanless, R.M., Fisher, P., Cooper, J., Parkes, J., Ryan, P.G., Slabber, M., 2008. Bait acceptance by house mice: an island field trial. Wildlife Res. 35, 806-811.

Weerakoon, M.K., Banks, P.B., 2011. Not just a matter of taste: palatability of bait markers is influenced by the need to search for alternative food. Wildlife Research 38, 596-602.

Wegmann, A., 2008. Land Crab Interference with Eradication Projects: Phase I Compendium of Available Information. Pacific Invasives Initiative, The University of Auckland, Auckland, New Zealand, p. 30.

Wegmann, A., Marquez, R., Howald, G., Curl, J., Helm, J., Llewellyn, C., Shed, P., 2007. Pohnpei rat eradication research and demonstration project: Pohnpei,
Federated States of Micronesia, 16 January-7 March 2007. Unpublished technical report, Island Conservation, Santa Cruz, CA, USA, p. 39.

Wegmann, A., Helm, J., Samaniego-Herrera, A., Smith, W., Jacobs, B., Drake, D., Smith, J., McKown, M., Henry, A., Hathaway, S., Fisher, R., 2008. Palmyra Atoll Rat Eradication: Biomarker Validation of an Effective Bait Application Rate, 19 June-5 July, 2008. Unpublished technical report, Island Conservation, Santa Cruz, CA, USA, p. 34.

Wegmann, A., Helm, J., Torr, N., Golding, C., Howald, G., 2009. Wake Atoll Rat Eradication Strategic Plan: Biomarker Study Trip Report (27 February-27 March, 2009). Unpublished technical report, Island Conservation, Kelowna, Canada, p. 16.

Wegmann, A., Buckelew, S., Howald, G., Helm, J, Swinnerton, K, 2011. Rodent eradication campaigns on tropical islands: novel challenges and possible solutions. In: Veitch, C.R., Clout, M.N., and Towns, D.R. (Eds.), Island Invasives: Eradication and Management. Proceedings of the International Conference on Island Invasives. Gland, Switzerland: IUCN and Auckland, New Zealand: CBB, p. 239-243.

Wegmann, A., Flint, E., White, S., Fox, M., Howald, G., McClelland, P., Alifano, A., Griffiths, R., 2012. Pushing the envelope in paradise: a novel approach to rat eradication at Palmyra Atoll. In: Timm, R.M. (Ed.), Proc. 25th Vertebrate Pest Conference. University of California, Davis, Monterey, California, USA, p. 48-53. 